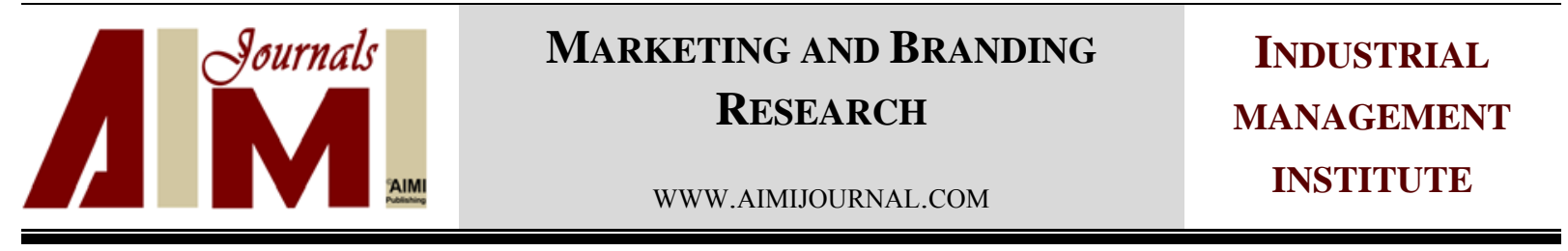

\title{
Mechanisms of regulation of commercial activities in variable demands of the global economy
}

\author{
Chingiz Ibrahimly ${ }^{1}$, Hamidreza Alipour ${ }^{2 *}$ \\ ${ }^{1} \mathrm{PhD}$ in Economy, Academy of Public Administration under the President of Republic of Azerbaijan, Baku City \\ ${ }^{2} \mathrm{PhD}$ in Economy, Department of Management and Economic, Rasht Branch, Islamic Azad University, Rasht, \\ Iran
}

\begin{abstract}
Keywords:

Commerce, Regulation, Mechanisms, Variable Demands

Correspondence:

Alipour@iaurasht.ac.ir

One of the most important side of market mechanism which is important to educate is commercial activities. As the evolution of economic relations, the level of commercial activities increase and its content and form change. Nowadays, in covering all fields of economic relations, commercial activities have great impact on economic development of the countries all over the world. Global and regional economic integration extends relevance between different economic issues and countries that their exemplifications are very significant. The formation of the global internet network development and e-commerce caused sweeping changes both over the world economy and activities of individual companies and enterprises. These changes even sometimes led to refusing some traditional ideas and provisions in economic theory. The trend of development of cross country integration reduction of the volume of world trade during last years proves the urgency of improvement in this field. The subject of the presented research article contains economic, institutional, and legal mechanisms of regulation of commercial activities in accordance with the constantly changing demands of the world economy. During scientific research, abstraction, comparison, and analysis techniques were used. Commercial activity of the regulatory processes in the economic activity of enterprises not only had a great impact on the development of individual institutions but also it sometimes affected the economic development of the country. In this regard, the results of the research can be used to improve the regulatory mechanisms and commercial activities.
\end{abstract}


Commerce is regarded as one of the oldest deal type of people and the history of commerce tends to be the history of civilization. Commerce is one of the means that different peoples own at various times to fulfil their demands (Powers, 1852). At different times, the attitude to the commercial activities of individual nations has never been too precise at all times. For example, Powers expresses that the Phoenici who occupied the narrow strip of coast land along the east of the Mediterranean Sea were the first navigators and carriers of goods by water. The Greeks were not necessarily considered as commercial people, being more dedicated to art, architecture and literature, nevertheless they had noticed the techniques of the Phoenicians and turned to be their competitors to a significant extent in commerce, and having eventually conquered them, inherited their trade.

In ancient Rome, patron of merchants and sellers, considered "Mercury" the god of trade, eloquence, travelers, communication, messengers, and trickery. It was explained by the fact that the Romans were, in a natural manner, statesmen and warriors rather than merchants. They were better adapted to control and direct than to trade or work. The rapid development of mercantilism in Western Europe in XV-XVI centuries and the international trade relations with the broad privileges related to the provision by the state of the merchant group has been the object of individual research scientists. Cantilon (1755) stated that trade relations bring benefits to government. Following this, it does not require many years to raise affluence to the highest point in a State; still fewer are required to bring it to poverty for lack of commerce and manufactures (Cantillon, 1755).

In XVIII century, entering the stage of development of the industry would necessitate the complex research trade relations. Classics of economics, Smith (1776) and Ricardo (1821), investigated different aspects of commerce relations as well as characteristics of international commercial agreements. Performing any idea about the business for profit by Smith is defined as one of the basic functions of the entrepreneur. Ricardo (1821) states the genuine commercial spirit, that which permanently protects the property of nations, is generally inconsistent with the dark and shallow policy of monopoly.

Important role of development in commercial activities of the country's economy is certain in the modern era. Commerce is an absolute requirement for effective operations and development of manufacturing, trade, services, construction, finance companies, and institutions and that reveals the need to approach the learning economic nature of commerce in a wider perspective. One of the main objectives in the realization of commercial activities complies entrepreneurs' individual interest; it is to gain profit. As well as commerce, activities have great importance for the fulfillment of important socialcivic duty.

\section{Factors Affecting the Commercial Activities of Enterprises}

Commercial relations can grow in conditions of economic independence of market objects. However, the market entities which carry out commercial activities can not be considered fully economically independent. Because in some cases for achieving the goal it is necessary to compromise. The independence of mutual commercial relations can be limited by the objective conditions of the external environment as well as the price, tax policy, trade secret, 
and other factors. So right now there is not independence in determination of price in fields affecting the overall development of any country's economy and social sphere.

Necessity of terms for the development of commercial activities brings studying these factors to fore. Commercial position of the enterprise is formed under the influence of internal and external environmental factors. External business environment that changes constantly takes place in the company's internal structure and is able to influence the outcome of commercial activity.

The external environmental factors affecting the commercial activities of enterprises include the state of the world economy and economic trends, the total situation of the national economy (macroeconomic), internal political, social, and demographic factors, approach to consumers, the activities of the bank, state regulations, material base, the behavior of competitors, transport infrastructure, and scientific and technological achievements.

All these factors interact with one another but on any particular circumstance the level of interaction may be different. The activity of entprise exits in interaction of the external environment of the markets and resources of all kinds as the result of the interaction is possible. The successful implementation of market conditions depends on using lots of factors in the complex case. In the absence of one of these factors, the development of the enterprise in the final result can be delayed. That is why the comprehensive and scientific approach to increasing the level of management of commerce activity is necessary.

In modern business conditions, company often faces with changes that can not be seen in advance in the business environment and it is difficult for its commercial activities. It can be noticed in establishment of joint ventures, implementation of joint projects, delivering products from foreign countries, and local businesses access to foreign market. Interaction between local enterprises and other countries' enterprises in international sector causes the failure of the first ones because of competition. In addition, this makes it necessary to increase the quality, as well to be known mechanisms and rules of government regulation.

\section{The Need for Regulation of Commercial Activities}

In various stages of development of mankind history, Power (1852) states that the commerce were complicated. However, throughout history, it would be wrong to underestimate the importance of the role of the state in the regulation of commercial activities. Actually, the development of trade and commercial relations with other countries is in the interest of every country in the commodity exchange. However, each state tries to use self-defense mechanisms maximum in trade relations with other countries.

Market economy is based on ensuring the rights and interests of commercial entities implementing the economic activity within the framework of laws, rules, and regulations. In terms of the country's socio-economic development and economic security the impact of state on the commercial activity of subjects was always topical issue. The business relations between the state and entrepreneurs have a positive effect on the level of development of market infrastructure. In a market economy, the impact of state on commercial activities is part of the state regulation of the economy.

In fact, the main regulators of the market environment are market conditions, supply, and demand situation in the market. However, a capitalism superstructure did not automatically 
emerge out of a thriving market economy with all that implies; other conditions were also required (Braudel, 1982). So, sometimes it is necessary to make minimum changes in the government's decisions related to market demand and supply (Samuelson \& Nordhaus, 2010). Firstly, the necessity of regulation of commerce activity is characterized with protection of the rights of all consumers ensuring the quality of goods and services made for them; controlling the process over the turnover in the state budget is important as well.

On the other hand, in addition to all the positive aspects, sometimes the world's super powered countries' commercial policies can create serious obstacles for developing countries. According to Nobel Prize winner Stiglitz (2002), in many cases, commercial interests and values have superseded concern for the environment, democracy, human rights, and social justice. Therefore, the state regulation of commercial activities, taking into account the national interests in the country covers comprehensive measures aimed at ensuring the commerce effectiveness in macro and micro economic levels.

\section{Mechanisms of Regulation of Commercial Activities}

In most countries, commerce and regulation of issues related to internal and external trade is centralized in ministry of trade (e.g. the United States, Russia, and Indonesia) or the ministry of commerce (e.g. People's Republic of China and Pakistan). These structures tend to have fairly broad powers. Organizational and administrative aspects of the regulation of commercial activities are approved in legislation. Legislation usually determines a variety of obligations related to businessmen's organizational and legal conditions that belong to the terms of their performance in a variety of organizational and legal obligations (e.g. to be in the register of trade, to allow the implementation of economic activity, to give license or franchise, and to open personal bank account). In some countries, these commitments are reflected in the commercial register.

In some countries for regulation of commercial relations civil code as well as the code of commercial or trade are in force. So, for the first time in France in 1807 and later in Spain in 1885, Germany in 1897, Japan in 1899, in the United States in 1952, Turkey in 1956, the Czech Republic in 1991, and Estonia in 1995 have adopted a code of trade or trade of commerce. In other countries, the lack of trade codes is usually offset by the adoption of special laws. For example, there have been recognized numerous laws related to trade right in UK in the 70-80s of the last century. They are fair trading Act 1973 c. 41., supply of goods (implied terms) Act 1973 c. 13., restrictive trade practices Act 1977 (repealed 1.3.2000) c. 19., unfair contract terms Act 1977 c. 50 ., and sale of goods Act 1979 c. 54.

Forms and methods of regulation of commercial activities in different countries are being improved sometimes considerably ranging from each other. In modern times, the state has many economic mechanisms of regulation of commercial activities. Mechanisms' changing conditions of commerce activity can help the regulation of its level which involve some restrictions in separate areas, certification of products, licensing of some types of commercial activities, implementing tax incentives or higher taxes, prevention from improper competition and of monopoly, the organization of the purchase of local producers by the state; insurance of company from currency and political risks during the export of goods, and environmental control and others. 
Almost in all countries, a number of state regulatory mechanisms or directly supervises of prices are being implemented. Results of these measures mainly have a greater impact on prices reflecting the condition in social sectors in the country and the level of consumer prices. These are typically water and energy resources, medicines, postal and telegraph, telephone prices, and rail fares.

Regulatory mechanisms provide balancing and stabilization of economy in the country, as well as the competitiveness of goods produced in foreign markets. In some countries, the main regulatory tools of foreign trade are variable compensations and custom duties. However, additional tools are also used for some key products. Therefore, products intended for abroad are strengthened special subsidies. In some cases, temporary foreign trade embargo, export taxes, export subsidies, import and export licenses are used as tools.

The international agreement has very significant role in the formation of national commercial (the trade) laws in individual countries. Having direct impact of country's regulation on the economies of other countries arouse necessity about exiting out of the national framework and and being implemented in international level. This regulation is based on bilateral contracts and agreements, regional multilateral agreements, and multilateral conventions. International society mainly aims at ensuaring high growth dynamics of international trade and tries to maximize the profit from this sphere in all countries.

\section{Experience in the regulation of commercial activities in the Republic of Azerbaijan}

From the 1990s in accordance with the development trend of international trade processes in Azerbaijan, it was begun to establish trade relations with other countries for measures regulation of commerce activity.

Commercial activity in the field of organizational and legal basis of economic entities in the Republic of Azerbaijan is reflected directly in the law of the country. The regulation of business activities in the country is held according to the constitution of the Republic of Azerbaijan, tax code, customs code, civil code of the Azerbaijan Republic, Milli Majlis decisions, orders of the Cabinet of Ministers, and other relevant laws and orders of the president of the country. In the economy of Azerbaijan in connection with the expansion of the rights of participants, the economy has significantly increased role in the development of the relations of private ownership, circulation, and scope of the contract of purchase contract. This is the basis of norms and rules established by civil code in contracts.

In Azerbaijan, despite the lack of law on commercial activities there have been some adopted laws that allow to realise this prosedure such as antimonopoly activities (04.03.1993), protection of consumer rights (19.09.1995), state registration of legal entities and state register (12.12.2003), the law on electronic commerce (10.05.2005), on advertising (03.10.1997), on commercial secrets (04.12.2001), and on regulated prices (30.05.2003). Since 2003, differentiation of taxes in the country is on the focus of the state. So, in order to increase economic activity and dynamic development of entrepreneurship, the degree of the income tax was reduced from $27 \%$ to $20 \%$ in $2002-2010$. Currently, the income tax rate is $20 \%$ for individuals engaged in entrepreneurial activity without establishing a legal entity. Value-added tax rate (the VAT) is 18 percent. Those whose volume of operations of not registered for VAT goals and tax 
calculated for each month is 120 thousand manat or lower than it, has the right to be a simplified taxpayers (in the capital $4 \%$, by region - $2 \%$ ) payers. If individuals or legal entities exceed this limit, they must be registered at the ministry of Taxes for VAT in 10 days. Note that, trade (wholesale and retail) and repair of vehicles' share of value increased from $6.4 \%$ to $7.9 \%$ in 2010-2014 in the country according to state statistics committee of the Republic of Azerbaijan.

Indicators of Table 1 allow to observe the tendency of stable development level in field of commerce activity in Azerbaijan since 2010. Especially the number of individuals in trade without establishing a legal entity engaged in business increased by 64109 units in 2010-2014 or about 50.3 percent. Table 1 presents the main indicators of trade enterprises in the Republic of Azerbaijan in 2010-2014.

Table 1

Main Indicators of Trade Enterprises in the Republic of Azerbaijan in 2010-2014

\begin{tabular}{|c|c|c|c|c|c|}
\hline & 2010 & 2011 & 2012 & 2013 & 2014 \\
\hline A number of trade enterprises with legal person status, unit & 30785 & 20370 & 21548 & 23240 & 24890 \\
\hline A number of individuals engaging in entrepreneurship without establishing a legal entity, $\iota$ & 127501 & 150686 & 171646 & $17632 \%$ & 191610 \\
\hline The number of items, food and mixed goods fairs and markets, unit & 122 & 128 & 128 & 126 & 124 \\
\hline The number of trading places in markets and fairs, unit & 37451 & 38377 & 38756 & 37661 & 36887 \\
\hline Retail trade turnover, compared with the previous year, $\%$ & 108.8 & 110.2 & 109.6 & 109.9 & 110.0 \\
\hline Trade enterprises from it & 111.1 & 112.5 & 112.1 & 112.6 & 111.9 \\
\hline The status of legal enterprise & 103.4 & 109.4 & 103.3 & 102.9 & 108.0 \\
\hline To private entrepreneurs engaged in trade without establishing a legal entity & 113.6 & 113.4 & 114.7 & 115.2 & 112.8 \\
\hline Agricultural products markets, fairs, $\%$ & 105.6 & 106.8 & 105.7 & 105.4 & 106.6 \\
\hline $\begin{array}{l}\text { The volume of paid services rendered to the population, compared to the previous year (thr } \\
\text { relative price), } \% \\
\text { from it: }\end{array}$ & 110.8 & 107.8 & 108.0 & 108.2 & 107.2 \\
\hline For legal entities & 107.6 & 106.3 & 106.3 & 107.0 & 105.7 \\
\hline
\end{tabular}

Until 2002, getting special licenses from various state agencies was required to realise for more than 240 types of commercial entrepreneurship activities. According to the decree of the president of the country dated $3^{\text {rd }}$ September 2002, licensing for most commercial activities was abolished (banking, insurance, audit, deliveries, and securities). Today, the studying of international experience continues in the country in order to create a favorable business environment. For example, according to the decree of the president of the Republic of Azerbaijan dated $21^{\text {st }}$ December 2015, the number of licensed areas reduced to 37 from 59 .

The president of the Republic of Azerbaijan signed an order (No. 2458, dated 25 October 2007) according to principle "one window" about the ensuring organization of "activities of business". According to the order, the national single state registration body of the Ministry of Taxes of the Azerbaijan Republic was established on $1^{\text {st }}$ January 2008 and its implementation was started. After the application of the system "one window" in Azerbaijan the number of procedures and time for its implementation decreased from 15 to 1 and from 30 days to 3 days, respectively. 
Under the influence of the changing requirements of government, orders and decrees are taken into consideration in economic processes in the field of business. So, on $15^{\text {th }}$ April 1998, by $80^{\text {th }}$ decision of Cabinet of Ministers of the Azerbaijan Republic approved the rules of commercial, residential and other services in the Republic of Azerbaijan. These rules, regardless of the form of property and subordination, all legal entities and individuals engaged in entrepreneurial activities without establishing a legal entity, regulated their trade (wholesale, retail and catering), domestic and other types of service activities (directly out of place).

According to No. 94 dated on $3^{\text {rd }}$ April 2014, Decision of the Cabinet of Ministers of Azerbaijan approved the rules of trade, catering, household, and other services in the Republic of Azerbaijan. In these rules focus was on trade, catering, household, and other services, as well as the main features of several important sales of food and non-food products. Thus, the mentioned spheres of commercial activities to implement the features have been improved taking into consideration the experience obtained during last years.

The Tariff (the price) Council of Azerbaijan Republic carries out state regulation of prices in the country. Regulation is carried out in accordance with the list of (work, services) commodities prices (the rates) regulating by state which was approved by the decision of the Cabinet of Ministers of the Azerbaijan Republic dated 2005 September 28 No. 178. Following this, 39 destinations covering natural monopoly, government monopoly, and monopolistic entities in various sectors of the economy (crude oil and oil refinery products, natural gas, electricity or thermal energy, and transport and communication services are all kinds of drinking and industrial water use, maintenance and repair of public housing, social rent for the lease of residential areas etc) included in this list. Except the fuel and energy sector, wholesale and retail prices in the agricultural sector and in other sectors of industry are not regulated by the state.

Azerbaijan demonstrates the interest in the development of e-commerce. On $10^{\text {th }}$ May 2005, the Law of Azerbaijan Republic on electronic commerce has been accepted. Some enterprises of our country in the field of development of commercial relations with foreign countries have achieved some success. In 1997, Azerbaijan has expressed intention to join the World Trade Organization. Azerbaijan's World Trade Organization membership is precisely associated with development of legislation and its compliance to requirements of international organization. Global economic integration of the legal framework of Azerbaijan in accordance with the requirements of the relevant changes were made to some normative legal acts and adopted new legal documents in order not to stay outside of WTO.

In order to achieve the extension and liberation of foreign economic as well as the trade relations, to define modern rules fulfilling the requirements of market economy in this field, rules regulating import and export operations in Azerbaijan Republic were approved by the further liberalization of foreign trade in the Republic of Azerbaijan by the decree of country's president, number 609 dated $24^{\text {th }}$ June 1997. In these rules, types of import and export operations have been enumerated, their implementation has been defined, accountimg rules related to operations and formalization process are shown, and a list of required documents are published. Integration of Azerbaijan into the world economy, quantitative and qualitative changes in the export-import operations made it necessary to conduct appropriate additions 
and changes to these rules repeatedly in 1998-2015. Export duties in the country have been abolished and the duties applied on imports in the country have been defined at the level of 0 15\%. Currently in Azerbaijan, import duties are considered low by international standards. In accordance with the legislation of the country, value-added tax is also calculated along with the customs duties on goods. According to the relevant decree of the president of Azerbaijan Republic, from 01.01.2009 the principle of "one window" has been applied in the inspection of goods and vehicles at the checkpoints of the state border of the country.

Thus, Azerbaijan has created conditions for the expansion of trade cooperation with other countries, as well as measures implemented in the direction of formation of legislation in the field of regulation of commercial activity.

\section{New Trends in the Development of World Trade}

Through long years, the apparent first condition tended to be a vigorous and expanding market economy. A whole range of factors, namely geographical, demographic, agricultural, industrial, and commercial contributed to this. However, in the last analysis, further development would have been impossible without the special and as it were liberating action of world trade. Long-distance trading was not everything, but it was the only doorway to a superior profit level (Braudel, 1982).

Although there is no joint opinion regarding the date of the formation of economic globalization among scientists, by accepting this process as a form of the flow of goods and production factors, it is mainly considered to be towards the end of the XIX century approximately in 1850-1870. Three growth periods of globalization are reported to be at different times. Researches show that the growth periods of globalization (about 1870-1914, 1950-1980, and 1980-2000) are the result of involving of more countries in international trade mainly due to cuts of transportation (the transport) spending and the reduction of trade barriers. On the other hand, in 1914, in the subsequent period of the beginning of World War I, the restriction of trade flows with protectionist measures led to the return within the national borders and in 1929 by the start of Great Depression, these measures have become more acute. In the $90 \mathrm{~s}$ of the last century, the expansion of the economic integration processes in the world by year, rise of the role of commerce in the economy of states, and continuation of this trend in the following years were predicted. There was enough evidence for this. McConnell and Brue (1999) showed the reason for the rapid growth of international trade after World War II such as transportation technologies, communication technologies, total decrease of tariffs, and existence of peace factors. In addition, joining of a number of new members as a result of political processes at different times has also affected the rise in the volume of international trade. For example, in the 90 s of the last century, joining of Poland, Hungary, the Czech Republic, East Germany, the countries of the former Soviet Union of the international trade, as well as the rise of the shares of the "Asian Tigers" (Hong Kong, Singapore, South Korea, Taiwan) in world exports could not escape the effects in this area (McConnell \& Brue, 1999).

According to the International Monetary Fund and the World Bank, the volume of trade (export) amount on the world in cash had increased from 4.1 trillion up to $\$ 23.2$ trillion and in real or physical terms, had increased by 3.4 times during the period of 1990-2013. 
(Kadochnikov \& Timur, 2014). Regarding the World Trade Organization, export of goods in the world was $2.3 \%$ in $2012,2.2 \%$ in 2013 , and $2.8 \%$ in 2014 . So, the World Trade Organization predicted that the volume of international trade would increase by only $2.8 \%$ in 2015 and $3.9 \%$ in 2016.

On the other hand, according to the World Bank, although the volume of merchandise trade in GDP over the world increased from $46.99 \%$ in 2010 to $50.74 \%$ in 2011 , it decreased to $48.46 \%$ in 2014 . The volume of exported goods and services in the world increased $18.2 \%$ in $2011,1.5 \%$ in $2012,2.7 \%$ in 2013 , and $1.7 \%$ in 2014 compared to the previous year. Exports of commercial services in the world exceeded export of goods increased by $6.2 \%$ in 2013 but in 2014, this figure was $4.3 \%$ for the rate of growth.

It should be noted that the declining trend in the volume of trade can be accepted as the result of the impact of the global economic crisis. Now "deglobalization" concept is being studied by the scientific community in different countries (Kadochnikov \& Timur, 2014; Karunaratne, 2012; Postelnicu, Dinu, \& Dabija, 2015). Research shows that the processes against the globalization of the world economy have been observed more often since the 2000s. Stiglitz (2006) stated that we have become economically interdependent more quickly than we have learned how to live together peacefully. Though the bonds that economic globalization forges - both the mutual interdependence that it implies and the greater understanding that arises from daily interactions - are a powerful force for peace, by themselves they are not enough; and without peace, commerce cannot exist (Stiglitz, 2006).

It should be noted that in recent years the decrease tendency of a steady upward trend since the 90s is not only the result of the influence of supply and demand factors, but also prompting many countries more aggressive protectionism by the influence of political processes occurring in the world. World experience has showed that in international trade some countries which is representative of ideas of liberalism prefer protectionist policies especially during the crisis. However, it has led to the creation of separate new regional associations with competing with each other and sometimes it has led to concluding preferential agreements, which are contrary to the World Trade Organization policy. In other words, regional and bilateral trade agreements had an exclusively positive impact on the liberalization of foreign trade in the period after World War II. In fact, expanded globalization process of the world economy has occurred as a result of intensive use of natural energy resources, globalization process of the world economy, exposure to certain changes under the influence of economic and financial crises, and changes under the influence of political tensions and conflicts.

In recent years, the declining trend in the volume of traditional trade happens in the background of obvious development of e-commerce in the world. Electronic retail trade has been global and observed growing confidence in the online sales of products all over the world. During the global financial crisis in 2008-2009, at a time when traditional trade faced hardships, the e-commerce continued to maintain high growth rates. Online retail remains the fastest growing retail channel. Online shopping has become a normal, mainstream and an everyday experience. Around $89 \%$ of Internet users in the United States are now online shoppers. Although online retailing is one of the smallest segments of the retail industry, constituting about $5-6 \%$ of the total retail market today, it grows at a faster rate than its 
offline counterparts with new functionality and product lines being added every day (Laudon \& Traver, 2014).

Online trading volume in the world increased by $18.3 \%$ in 2013 based on "eMarketer" report in August 2015. In 2014, the figure which increased 22.2\% reached $\$ 1.3$ trillion and this consists $5.9 \%$ of all retail trade. According to the company's prognosis, online-trading volume in 2018 will reach $\$ 2.5$ trillion or $8.8 \%$ of all retail trade.

In near future the important role of e-commerce is not in doubt. Opportunities of getting more profit in e-commerce make it necessary to have more new ideas in this field. Formed in the late 2000s, sales of goods and services in commercial or social field began to develop particularly through mobile commerce. According to "eMarketer" Inc.-in araşdırmalarına əsasən, in 2013, mobile commerce is expected to generate around $\$ 39$ billion overall. In 2013 , over $50 \%$ of online purchasers are expected to make a purchase using a mobile device and it is estimated that this percentage will grow to over 75\% by 2017 (Laudon \& Traver, 2014).

Today, the scope of e-commerce covers the conditions from real estate market to securities market. E-commerce essentially covers the entire collection of production and consumption of goods. E-commerce retail is not limited with the framework of internetshops. Production facilities as well as suppliers of raw materials apply this type of commercial relations. Some industry analytics believe that by $2020,20 \%$ of all retail sales will be held by e-commerce (Laudon \& Traver, 2014).

It can be concluded that, in the near future companies that can not estimate the potential of e-commerce will gradually lose its position under pressure of opponent more effectively using e-commerce. E-commerce affects the regional and interdisciplinary commercial relations too. E-commerce defines new ways of changing commercial goods over the world and as a result it can cause improvement of territorial division of labor place in the world and achive proportionality in the region.

\section{Conclusion}

The variable demands of the world economy requires implementation of different measures in the sphere of the development and regulation of commercial activities. Considering this, for supporting the strengthening of macroeconomic development optimal compromise government regulation and market mechanisms are also significant. The modern term structure of commodity markets and its information coverage requires development. Commercial policy must centralize the priority directions of development of individual elements in commercial infrastructure.

In recent years regarding the general background of the weakening world trade, the number of commercial transactions carried out via the Internet increases. However, the approach like "only level of economic integration with other countries and access of produced local products to international markets" is not enough to increase the level of commercial activities in the future. One of the main tasks in front of the regulation policy of the commercial activities especially in developing countries is to take into account all possible external economic effects creating the necessary conditions for the development of internal consumption in the country market. 


\section{References}

Braudel, F. (1982). Civilization and capitalism, 15th-18th century: The wheels of commerce. Berkeley, CA: University of California Press.

Cantillon, R. (1755). Essai sur la nature du commerce en général. London: The Royal Economic Society.

Kadochnikov, P., K., \& Timur, A. (2014). On the question of the presence of de-globalization in world trade. Economic Policy, 5, 127-149.

Karunaratne, N. D. (2012). The globalization-deglobalization policy conundrum. Modern Economy, 3(4), 373-383.

Laudon, K. C., \& Traver, C. G. (2014). E-commerce: Business, technology, society (10 ${ }^{\text {th }}$ ed.). Boston: Addison Wesley.

McConnell, C. R., Brue, S. L. (1999). Economics: Principles, problems and policies (14 ${ }^{\text {th }}$ ed.). Boston: McGraw-Hill, Irwin.

Postelnicu, C., Dinu, V., \& Dabija, D. C. (2015) Economic deglobalization - from hypothesis to reality. Economics \& Management, 18(2), 4-14.

Powers, O. M. (1852). Commerce and finance. Chicago: Powers \& Lyons.

Ricardo, D. (1821). On the principles of political economy and taxation ( $3^{\text {rd }}$ ed.). London: John Murray.

Samuelson, P. A., \& Nordhaus, W. D. (2010). Economics (19 ${ }^{\text {th }}$ ed.). New York: McGraw-Hill.

Smith, A. (1776). An inquiry into the nature and causes of the wealth of nations. London: Methuen and Co., Ltd.

Stiglitz, J. E. (2006). Making globalization work ( $1^{\text {st }}$ ed.). New York: W.W. Norton. 